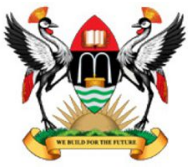

East African School of

Higher Education Studies \& Development
Makerere Journal of Higher Education

ISSN: $1816-6822 ; 10$ (2) (2019) $93-118$

DOI: http://dx.doi.org/10.4314/majohe.v10i2.8

(C) The Author(s) 2019

Reprints \& permission: EASHESD

http://ajol.info/majohe

\title{
Instructional Leadership and Lecturers' Job Performance in Public Universities in Uganda
}

\author{
Edith Namutebi ${ }^{1}$ \\ ${ }^{1}$ Kampala University [E-mail: edithnamutebi29@gmail.com]
}

\begin{abstract}
Uganda's public universities are still grappling with the challenge of lecturers' job underperformance. While a growing body of research has identified various factors to explain this underperformance, it has not paid much attention to the analysis of whether instructional leadership is among the causes and if it can provide a solution to this challenge. Therefore, this study provides this analysis. The study employed a cross-sectional correlational survey involving collection of questionnaire data from 341 lecturers and 35 heads of departments (instructional leaders) selected from Makerere University and Kyambogo University using stratified sampling. The data was analysed using descriptive, data transformation, and linear regression analysis. Findings established instructional leadership as a positive and significant predictor of lecturers' job performance. These findings suggest that improving instructional leadership by availing lecturers with adequate instructional resources and supervising and monitoring them effectively can improve their job performance. Accordingly, the study recommends to the management of Uganda's public universities to stock sufficient teaching resources and to ensure that their heads of departments play their supervisory and monitoring roles effectively.
\end{abstract}

Keywords: Instructional management; Performance management; Reform.

\section{$1 \quad$ Introduction}

Uganda liberalised university education in the early 1990s with the aim of widening access to it and maximising attainment of its purpose of preparing the highest level of human capital the country critically needed to foster innovative and sustainable national development (Sanga, 2017). However, realising this purpose does not just happen. Research has shown that it is determined by various factors at the heart of which is lecturers' job performance (Wong \& Yuan-Li, 2019). Lecturers' job performance refers to the extent to which lecturers complete the teaching, research and community service tasks, responsibilities 
and activities intended to facilitate student learning and achievement of desired educational outcomes (Alfagira et al., 2017; Onoyase, 2017; Victor \& Babatunde, 2014; Naseer, 2010). The extent to which lecturers complete their jobs plays a critical role in enabling a university to achieve its purpose. Lecturers who perform their jobs as expected enable their university to achieve its purpose as desired, but the reverse occurs when there is lecturer job underperformance (Hassel \& Ridout, 2018). The latter is unfortunately the situation facing public universities in Uganda (Sanga, 2017).

Previous research has shown that the majority of the lecturers in Ugandan public universities are underperforming their jobs. Specifically, the study of Nassuna (2013) indicates that over $80 \%$ of Makerere university lecturers who participated as respondents revealed that they did not teach all the lectures assigned to them and $70 \%$ were not regularly available to supervise research students allocated to them. The study of Kakulu (2016) revealed that over 78\% of Kyambogo University lecturers who participated as respondents failed to teach all the lectures assigned to them, with $67 \%$ of them being inadequately prepared prior to delivering most of the lectures to students and $56 \%$ delaying to evaluate students, thereby causing the students to miss graduating in time, especially at the postgraduate level. According to Ddungu (2017), most of the lecturers assigned to supervise research students do not guide these students as scheduled even when the students make efforts to fix appointments prior to meeting them. The lecturers frequently call off the appointments at the last minute and postpone the supervision to another unfixed date, citing being caught up in other research projects. Furthermore, the level of most of the lecturers' participation in community service is far below expectation (Ddungu, 2018a), and their involvement in research and publication leaves a lot to be desired (Ddungu, 2018b). Similar findings appear the study Wakida, Maling and Obua (2018) conducted at Mbarara University of Science and Technology. The preceding studies indicate that the majority of lecturers in most of the public universities in Uganda are underperforming their jobs. This underperformance however, does not take place in a vacuum but under the influence of various factors.

Different studies have been conducted to establish these factors. Some of the studies have identified personal factors such as job dissatisfaction and work stress, among others (Ssesanga \& Garrett, 2005). Other studies have identified university-based factors such as institutional management and financing (Liang et al., 2016), observed governance policies, academic staff remuneration, poor work conditions (Alfagira et al., 2017), administrative leadership (Kezar \& Holcombe, 2017), and most of all, instructional leadership (Ersozlu \& Saklan, 2016; Lineburg, 2010), among others. However, those that have identified instructional leadership are generally few at the university level and entirely lacking in the specific context of Uganda's public universities. Consequently, it 
is not clear whether and how instructional leadership explains the job underperformance of lecturers in these universities.

The few empirical studies that have analysed instructional leadership include Hallinger and Murphy (1985) and Hallinger (2003) among others. These studies indicate that as a concept, instructional leadership dates back to the 1980s when researchers developed more interest in analysing the role it plays in facilitating desired student learning and educational outcomes (Hallinger, 2003). This concept has since been defined by different scholars with some such as Hallinger and Murphy (1985) delineating it as a role that a leader in an educational institution plays in form of defining the institution's mission, managing its instructional programme, and promoting a positive teaching climate. Such a leader differs according to the educational institution. In primary and secondary schools, this leader is the head teacher or principal, but in a university, officials who play the instructional leadership role are the heads of departments, since these are the direct supervisors of the lecturers (Ersozlu \& Saklan, 2016). The purpose of this paper is to investigate how each of dimensions is conducted in public universities in Uganda and how it accounts for lecturers' job performance. Consequently, the specific objectives of the paper are to (a) establish the current state of lecturers' job performance and analyse how the way their heads of departments (b) define their universities' missions, (c) manage instructional programmes and (d) promote a supportive teaching-climate influences this job performance.

\section{$2 \quad$ Related Literature}

\subsection{Theoretical Review}

This study was grounded in Burns' (1978) transformational leadership theory viewed from the perspective of Hallinger and Murphy's (1985) model of instructional leadership. This theory advances a view that exemplary leadership is not that which focuses on fostering mere follower-compliance through motivation involving giving or withholding rewards; it is that which engages in introducing and promoting changes that are mutually beneficial to the leader, the led and their organisation, community or nation as a whole (Burkus, 2010). Within the context of Hallinger and Murphy's (1985) model, this view implies that instructional leadership is not concerned with giving or withholding rewards to ensure lecturer compliance; it is about adopting and encouraging instructional changes that benefit the instructional leader, lecturers, their university and students.

The transformational leadership theory asserts that for one (such as an instructional leader) to be considered effective, one has to demonstrate the 
following: individual consideration, intellectual stimulation, inspirational motivation, and idealised influence (McCleskey, 2014). In the context of Hallinger and Murphy's (1985) model, all these dimensions work simultaneously to enable the instructional leader to define and communicate the university's mission, manage its instructional programme and promote a supportive teaching performance in a manner that convinces and inspires lecturers to perform their jobs effectively (Hallinger, 2003). By individualised consideration, this theory refers to the degree to which a leader (or instructional leader) attends to each follower's (or lecturer's) needs as an empathetic mentor, listening to the follower's concerns and grievances, giving the follower support, keeping open communication with and giving each follower positive challenges (Yu, 2013). Individualised consideration involves a leader respecting followers, celebrating their contributions, and creating opportunities for them to express their aspiration for self-development and intrinsic motivation to perform assigned work (McCrimmon, 2008). Intellectual stimulation is the degree to which a leader challenges assumptions, solicits followers' ideas when taking risks, encourages creativity in followers and nurtures and develops followers to think independently (McCrimmon, 2008). Learning is valued and unexpected situations are regarded as opportunities to learn; a leader allows followers to ask questions, think deeply about things and figure out better ways of executing their tasks (Nusair et al., 2012).

Inspirational motivation refers to the degree to which a leader (instructional leader) articulates a vision and mission (such as a university mission) in an appealing, inspiring, precise, understandable, and engaging manner to followers (Chen, 2014, 2017). It involves a leader setting clear goals (such as curriculum goals) and communicating optimism about them, challenging followers (teachers) with high performance standards, providing meaning for the task at hand, and encouraging them to believe in their abilities (Barth-Farkas \& Vera, 2014). The leader inspires in followers not only a strong sense of meaning and purpose of what they do but also the energy that drives them forward (Mbithi et al., 2016). The leader communicates the mission in an understandable, precise, powerful and engaging manner that persuades followers' willingness to invest more effort in their tasks, and to be optimistic about the future and to have pride in they achieve for their organisations and themselves as well. Idealised influence is described as a leader's behaviour that inspires followers because it is exemplary and ethical, instils pride in followers and makes them look to him or her as a source of admiration, respect and trust, as a role model to emulate and with whom they want to identify (Ndiritu, 2012). Hughes (2014) summarised idealised influence as the followers' personification of their leader's values, beliefs and ways of doing work that contributes to the pursued mission and vision. 
The transformational leadership theory has however, come under attack. Critics argue that its multifaceted nature tends to produce inconsistent results (Day \& Harrison, 2007). While some studies have established that it is a significant predictor of positive results, others have come up with insignificant findings. Its rationale is also sometimes abused by leaders who pretend to be transformational when they are purely transactional in the actual sense. Despite these criticisms, transformational leadership theory is recognised as valuable and has been widely used in research about how leaders influence the performance of their subordinates (Sadeghi \& Pihie, 2013). It is for this reason that this theory was selected to guide this study. Its selection was particularly based on extant scholarship that had revealed that instructional leaders who exercise transformational leadership through each of its dimensions inspire teachers to perform to or beyond expectation (Money, 2017).

Such a connection has in fact been validated for almost 30 years since the theory was first proposed by Burns (1978) based on empirical research that established a strong and positive correlation between transformational leadership and performance outcomes at the individual, group, and organizational levels. Hallinger (2003) applied this theory to Hallinger and Murphy's (1985) model of instructional leadership and found out that school leaders who exercise instructional leadership through the dimensions proposed by this theory are able to effectively define their schools' missions, manage the schools' instructional programmes, and promote a positive teaching-climate not exclusively but inclusively. In so doing, they motivate teachers to perform their jobs, thereby contributing optimally to the achievement of the desired learning outcomes. These findings are however, yet to be validated in the specific context of public universities in Uganda. It is for this reason that this study was conducted following the conceptual framework in Figure 1.

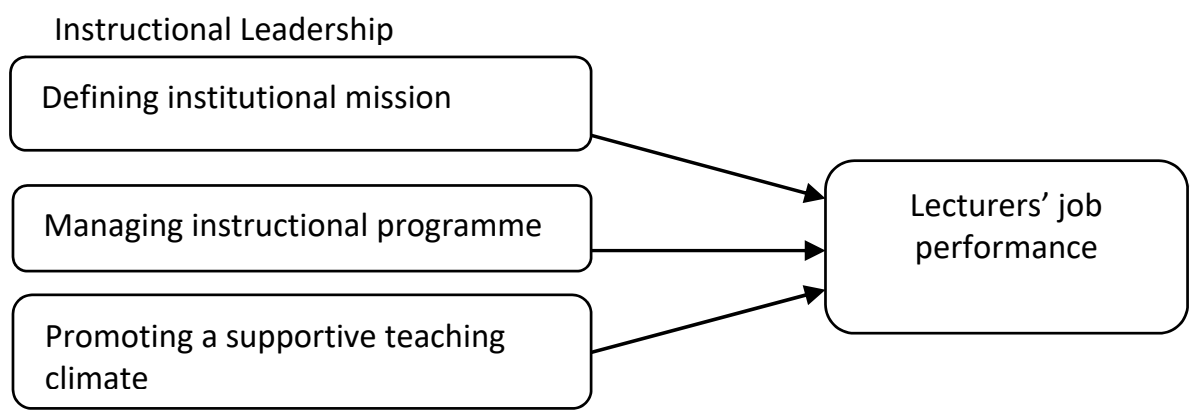

Figure 1: Conceptual framework

Source: Adapted from Hallinger and Murphy (1985) and Hallinger (2003). 
The conceptual model in Figure 1 assumes that lecturers' job performance is determined by how instructional leadership is exercised. Accordingly, instructional leadership was considered the independent variable and lecturers' job performance as the dependent variable. As the model indicates, instructional leadership was measured in terms of its dimensions identified by Hallinger and Murphy (1985), including defining institutional mission, managing the instructional programme and promoting a school climate. Lecturers' job performance was measured in terms of teaching, research and community service.

\subsection{Lecturers' Job Performance}

Lecturers' job performance has attracted different studies (Alfagira et al., 2017; Onoyase, 2017; McCarthy, 2015; Victor \& Babatunde, 2014). Specifically, Onoyase (2017) defined lecturers' job performance using the outcomedimension, thereby describing it as the extent to which academic staff members achieve educational outcomes expected of them. While this definition is valid, it was not applied in this study because of the difficulties associated with measuring educational outcomes. Taking the process dimension adopted in this present study, Victor and Babatunde (2014) described lecturers' job performance as the degree to which academic staff members complete their teaching responsibilities, which include lecture planning, research, and community service. Although these researchers' approach is used in this present study, they related the process dimensions of lecturers' job performance to motivation but not instructional leadership. A similar approach was applied by Alfagira et al. (2017) but these researchers also related this performance to motivation. According to McCarthy (2015), lecture planning focuses on using the content outline of the assigned course unit(s) and the learning objectives it seeks to achieve to search for and select relevant subject matter for a particular lecture, segmenting this subject matter into specific content sections and subsections, and determining which subject matter to cover within the allocated time. This author continued to show that lesson planning involves determining relevant teaching/learning materials and a pedagogical method to use in order to effectively deliver the subject matter in a manner that cultivates and maintains student attention, interest, and participation necessary to realizing set learning objectives. McCarthy (2015) was however, descriptive as he did not go beyond explaining what lesson planning involves.

Furthermore, lecturers' job performance includes delivering lectures to students as scheduled by the timetable, and evaluating the students by giving and marking coursework, setting tests and examinations, invigilating and marking them, and submitting their results/marks for final assessment, grading and accrediting (Igbojekwe et al., 2015). This performance further involves 
supervising research students by creating adequate time for guiding them through their research proposals, projects and dissertations (Ddungu, 2017). The performance further involves conducting research and publishing findings in reputable academic journals, or using the findings to write textbooks, textbook chapters and articles in media outlets and documentaries (Kakulu, 2016). It further involves lecturers participating in community service by carrying out activities such as public scholarship, participatory research, community partnership, public information networks, and civil literacy scholarship (Ddungu, 2018a; Nhamo, 2013). Generally, while existing literature describes what lecturers' job performance entails, it does not relate it to instructional leadership within the context of public universities in Uganda. However, the description of this performance it provides provided the indicators that were used to measure it in this study.

\subsection{Mission and Lecturers' Job Performance}

Different scholars have explained how the way an organisation's mission is defined influences how workers perform their jobs. Specifically, writing about what motivates people, Pink (2009) noted that the forces that drive how people perform at the workplace, but their performance increases when what motivates them is a clearly defined purpose or mission. The most productive, satisfied, deeply motivated and high performing people are those that connect their desires to a mission larger than themselves. This observation suggests that a clearly defined mission drives people to perform their jobs optimally. The observation is however, generalised to all people, but needs to be validated for specific categories of employees such as lecturers in public universities in Uganda.

In addition, Hallinger (2003) analysed how defining a school mission influences the role of a teacher in facilitating desired learning. This researcher observed that defining a school mission involves stating a clear purpose for a school, translating the mission into clear goals, setting performance standards necessary to achieve the goals and communicating the standards to the teachers articulately. Hallinger found out that an instructional leader who defines a clear school purpose, translates the purpose into clear school goals based on the national curriculum, sets clear performance standards by which the goals should be pursued, and communicates the standards inspires teachers to perform their jobs as desired. This is because the set performance standards motivate teachers to perform their jobs in a way that ensures that the standards are met. Hallinger's observations suggest that an instructional leader who clearly spells out an educational mission, translates the mission into clear goals and performance standards, and articulates these standards clearly encourages teachers to perform their jobs effectively. The reverse is also true. These observations were however made within the context of elementary schools in order to develop conceptual 
model linking instructional leadership to educational outcomes. While the model has been tested in various school settings such as those in Australia (Hallinger, 2007), not much effort has been made to test it within the context of Uganda's public universities.

Besides Hallinger, Adams (2016) found out that the way a school mission is defined influences how teachers perform their jobs in terms of how they commit their time, efforts and energies to the worthy cause of educating students. These findings however contrasted those already presented above; for they revealed no significant relationship between defining an educational mission and teachers' job performance. Teachers felt the same job stress and registered almost the same level of effectiveness in teaching in spite of the changes introduced in the definition of their school's mission. Adams (2016) was however, conducted in a primary school in Minnesota, United States. To recap, existing literature shows that how an instructional leader defines an educational mission influences the way lecturers perform their jobs. However, this literature is deficient about the nature of this influence within the context of public universities in Uganda. This is void filled in this study.

\subsection{Management of Instructional Programme and Job Performance}

The way an instructional leader manages instructional programme and how it influences teachers' job performance has attracted a number of researchers some of whom are Hallinger (2003) and together with his earlier colleague Hallinger and Murphy (1985). These researchers analysed the managing of instructional programme as a role an instructional leader plays in form of determining academic programmes and their goals in line with the university curriculum; mobilising resources needed to implement the programmes; directing, supervising and monitoring the programmes' implementation; and evaluating lecturers regularly to establish progress in realising desired student learning and talent growth (Pearce, 2017). The fact that these roles are executed to ensure realisation of desired learning outcomes implies that they influence how lecturers perform their jobs (Hompashe, 2018). This is the influence analysed in this study for the public universities in Uganda.

In addition, Lyonga (2018) examined the influence of supervision on teachers' work performance. The findings indicate that instructional supervision has a positive influence on different aspects of teachers' job performance. In particular, instructional leaders positively influence teachers' job performance when they regularly engage in classroom visits and observation of teaching, examination of teaching and learning methods used by teachers during supervision, and regular checking of teachers' schemes of work, lesson plans, correction of teachers' lesson plans, and holding meetings with teachers individually and as groups to provide guidance on how to improve teaching and 
learning activities. A similar conclusion was reached by Yousaf et al. (2018). However, while Lyonga's study was conducted in primary schools in Konye Sub-Division in Cameroon that of Yousaf et al. (2018) was conducted in the same schools in Pakistan. Accordingly, the findings of these studies need to be validated in Uganda, particularly in public universities were lecturers do not perform their jobs as expected.

Furthermore, Ndungu et al. (2015) conducted a study to examine the influence of teacher monitoring and evaluation by principals on effective teaching and learning in public secondary schools in Githunguri District. They analysed monitoring as a role by which an instructional leader engages in continuous and systematic checking and observing of teachers as they carry out assigned responsibilities. They examined evaluation as a role an instructional leader does by assessing, judging, appraising and determining how teachers have done their responsibilities and providing feedback about the strengths, weaknesses and solutions needed to correct the weaknesses in order to improve where necessary. They further noted that this evaluation involves comparing what teachers are expected to do (performance standards) to what they have actually done in order to establish the difference and how to close it. Findings revealed that instructional leaders who assessed teachers' preparation of schemes of work and lesson plans, classroom teaching through discussing with students about the taught content and how it is imparted, and teachers' involvement in fostering desired student discipline and career guidance enabled their teachers to significantly improve in each of these areas of their job performance. These scholars however, focused on secondary schools, not public universities.

Laska (2016) examined teacher monitoring and evaluating roles a school principal plays through the process of observation in the classroom and their influence on the performance of teachers. The findings obtained from the examination revealed that school principals who carried out these roles by engaging in planning for teacher observation in classroom, actual observation, and evaluating the teachers and providing feedback after observation enhanced teachers' job performance. Indeed, the instructional leaders helped improve delivery of more updated lesson content using the most appropriate pedagogical techniques. They also made teachers' classroom teaching more interactive, and evaluation of student attentiveness and learning more focused. Laska's (2016) study was however, conducted in primary schools, thereby leaving a question as to whether its findings are valid in a secondary school context pending an empirical answer. Generally, literature suggests that the way an instructional leader manages an instructional programme influences teachers' job performance. The literature is however, lacking as far as the nature of this influence in public universities in Uganda is concerned. This study is needed to address to this lack. 


\subsection{Teaching Climate and Lecturers' Job Performance}

Different scholars have examined how promoting a supportive teaching-climate by a school principal influences teachers' job performance. Among these scholars are Hallinger $(2003,2007)$ and Hallinger and Murphy (1985) who pointed out that promoting a positive teaching-climate involves a school principal protecting instructional time, promoting professional development, maintaining high visibility, providing incentives for teaching, and providing incentives for learning. These scholars asserted that a school principal who engages in these roles creates a school environment in which teaching and learning take place in conducive and facilitative atmosphere that translates into optimising learning and educational outcomes.

Dhuey and Smith (2014) are other researchers who observed that protecting instructional time involves an instructional leader ensuring that teachers teach all the lessons assigned to them, are available at school to attend to students' nonclassroom academic and non-academic needs such research supervision. According to Laska (2016), promoting professional development involves instructional leaders giving teachers professional guidance and creating opportunities for them to pursue career development. Providing teachers with incentives for teaching involves an instructional leader giving rewards for outstanding teaching reflected through student achievement (Kipsangut, 2012), and attending to their grievances (Ndungu, 2015). Giving students incentives for learning involves an instructional leader providing necessary learning facilities such as necessary library services, laboratory facilities, recreation facilities, and rewards for outstanding academic and non-academic performance (Hirshleifer, 2016). Promoting a supportive teaching-climate also involves an instructional leader giving students opportunities to express their concerns and grievances in open student forums or discussions, and following up to check whether the grievances are addressed either by the teachers or the top administration (Ndungu, 2015). It is noted that while each of the cited studies explained how the instructional leader promotes a positive teaching climate, they did not delve into how the created climate influences teachers' job performance. This is the gap that this study filled.

Generally, extant scholarship explains how an instructional leader promotes a supportive teaching climate, with a few studies indicating how the promoted climate influences teachers' job performance. However, all the studies were conducted outside Uganda, and mostly in primary or secondary schools. This suggests that extant scholarship does not reflect how the instructional leaders in Uganda promote a supportive teaching-climate and how what they do influences teachers' job performance. This study was therefore needed to address this gap within the context of Uganda's public universities. 


\section{$3 \quad$ Research Methods}

This study employed a cross-sectional correlational research design, since its purpose was to examine the nature of the relationship between instructional leadership and lecturers' job performance. This research design facilitated the analysis of this relationship using first hand quantitative data collected in a short time using questionnaires administered to a relatively large sample (Creswell \& Creswell, 2018). The study population consisted of lecturers of two Ugandan public universities, which included Makerere University and Kyambogo University. These two universities were considered because they were the largest public universities in Uganda both in terms of number of departments, academic staff and students. Specifically, $70 \%$ of the 8096 academic staff members in public universities in Uganda were in these two universities (National Council for Higher Education, 2018). They were therefore largely representative of all the public universities in Uganda. The expected sample size of the study was determined using Slovene's formula below:

$$
n=\left[\frac{N}{1+\mathrm{Ne}^{2}}\right]
$$

Where $\mathrm{n}$ was the sample size to compute, $\mathrm{N}$ the population size and e the margin of error allowed statistically when determining a representative sample size. The sample was selected at the $95 \%$ level of confidence. Substituting $\mathrm{N}=70 \%$ of $9096 \approx 6367$ and $5 \%$ for $\mathrm{e}, \mathrm{n}$ in the formula above was 376 . This sample was proportionally selected from the two universities. Makerere University had a total of 3976 lecturers and Kyambogo University had 2391 lecturers. Therefore, lecturers selected from Makerere university were $(3976 \div 6367) \times 376=235$ and those selected from Kyambogo University were $(2391 \div 6367) \times 376=141$. These lecturers were selected using stratified sampling, a probability sampling technique that involves selecting respondents from different categories based on a criterion that each category is needed to provide a deeper understanding of a phenomenon under investigation (Creswell \& Creswell, 2018). This sampling technique helped stratify the academic staff members into heads of departments and lecturers. Heads of departments were selected as instructional leaders, since in a university setting they are the instructional supervisors over the lecturers.

Data was collected using a self-administered structured questionnaire, since the lecturers were literate enough to read the questions and write their responses. The questionnaire had close-ended items that measured the variables of the study using the Likert scale of responses running from Strongly Disagree $(\mathrm{SD}=1)$ through Disagree $(\mathrm{D}=2)$, Somewhat Agree $(\mathrm{S}=3)$ and Agree $(\mathrm{A}=4)$ to Strongly Agree $(\mathrm{SA}=5)$. The questionnaire's Content Validity Index was 0.878 and its Cronbach Alpha coefficient was 0.846. These indices meant that the 
questionnaire was highly valid and reliable. The questionnaire was administered after seeking each lecturer's consent and cooperation by explaining the purpose of the study while underscoring the fact that the study was purely academic. The data was analysed using descriptive, data transformation and linear regression techniques supported by the SPSS (Version 22).

\section{$4 \quad$ Findings}

The first objective of the study was to establish the current state of lecturers' job performance. To achieve this objective, the selected respondents were asked to use the Likert scale of responses explained above to assess how they performed the various indicators of their job performance as lecturers. Respondents who disagreed and those who strongly disagreed to the indicators were both construed to have revealed that poorly performed their jobs. Those who somewhat agreed and those who agreed were both interpreted to have shown that they performed their jobs but below expectation. Those who strongly agreed were construed to have revealed that they performed their jobs as expected. The findings obtained from descriptive analysis of the assessment appear in Table 1. 
Table 1: Mean Scores on Job Performance

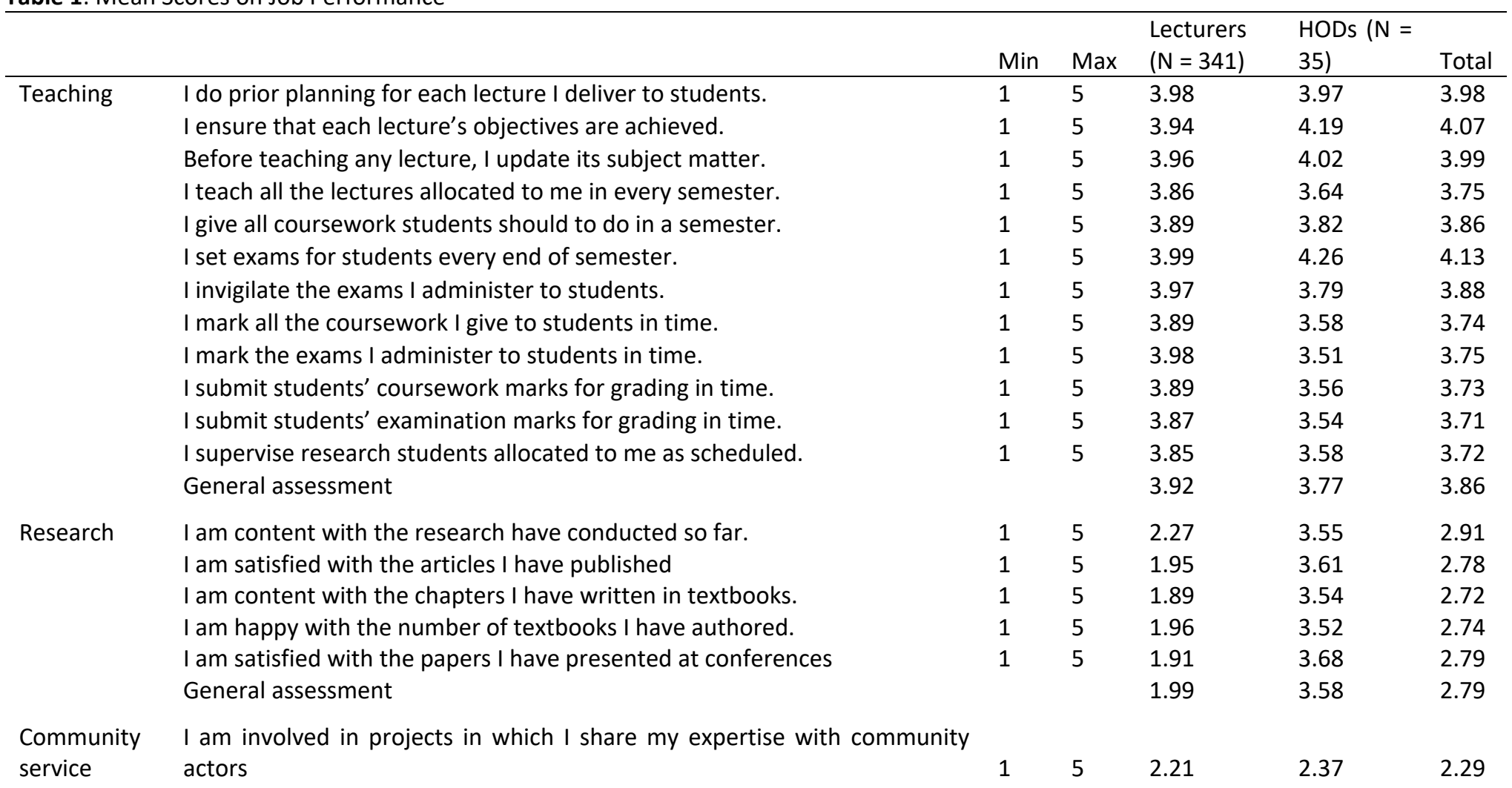


I negotiate with companies to provide internship to my students

I have developed applications to solve societal problems

I participate in debates on solutions to issues of public interest

I conduct research in which the community is beneficially included

I collaborate with community groups in mutually beneficial projects.

I communicate with the general public about issues of public interest.

General assessment

\begin{tabular}{lllll}
1 & 5 & 1.55 & 1.68 & 1.62 \\
1 & 5 & 1.59 & 1.79 & 1.69 \\
1 & 5 & 1.86 & 1.66 & 1.76 \\
1 & 5 & 1.71 & 1.81 & 1.76 \\
1 & 5 & 1.57 & 1.64 & 1.61 \\
1 & 5 & 2.26 & 2.29 & 2.28 \\
& & 1.82 & 1.89 & 1.86 \\
& & 2.58 & 3.08 & 3.84 \\
\hline
\end{tabular}


The minimum and maximum values in Table 1 indicate that there were respondents who strongly disagreed $(\min =1)$ to all the indicators of their job performance and those who strongly agreed $(\max =5)$. This suggests that there were lecturers who poorly performed and those performed their jobs as expected. The mean values however, were either close to ' 4 ' or close to ' 2 '. This reveals that on average, lecturers' job performance varied between poor and below expectation. In particular, the mean values corresponding to the indicators of teaching were all close to '4', suggesting that the lecturers performed below this dimension of their job below expectation. The mean values corresponding to research were close to ' 2 ' for lecturers and close to ' 4 ' for heads of departments. This suggests that while lecturers poorly performed the research dimension, the heads of departments performed it below expectation. With respect to community service, all the mean values were close to ' 2 ', suggesting that community service was poorly performed. The mean values corresponding to the 'overall' assessment of lecturers' job performance as a whole were all close to ' 3 '. This reveals that in general, the lecturers who participated in the study underperformed their jobs on average.

The second objective of the paper was to analyse how the way heads of departments defined their universities' missions influenced lecturers' job performance. Before analysing this influence, effort was made to ask respondents to assess how the heads of departments defined their universities' missions. Descriptive findings obtained from the assessment are summarized in Table 2. 
Table 2: Mean Scores on Departmental Mission

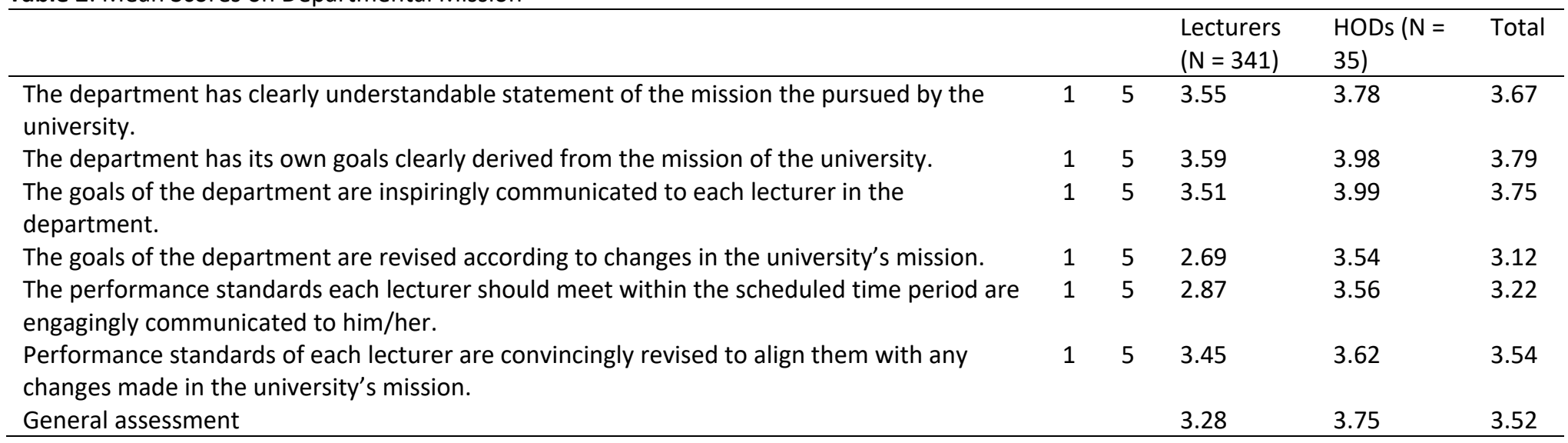


The findings in Table 2 indicate that there were respondents who showed that their heads of departments did not define the universities' missions $(\min =1)$ and those who indicated that these missions were clearly defined $(\max =5)$. The mean values were either close to ' 3 ' or close to ' 4 '. This suggests that on average, respondents somewhat agreed or agreed, thereby showing that the heads of departments defined the universities' missions, but below lecturers' expectation.

The responses in Table 1 and those in Table 2 were subjected to data transformation using the arithmetic technique provided by the SPPS program to build global variables that were named 'Lecturers' job performance' and 'Mission definition', respectively. Thereafter, linear regression was carried out to establish how Mission definition predicted (influenced) lecturers' job performance. Findings are presented in Table 3.

Table 3: Prediction of lecturers; job performance by mission definition

\begin{tabular}{lllllllllll}
\hline & \multicolumn{3}{c}{ Std. } & & & & \multicolumn{5}{c}{ Adjusted } \\
Predictors & $\mathrm{B}$ & Error & Beta & $\mathrm{t}$ & $\mathrm{Sig}$. & $\mathrm{R}$ & $\mathrm{R}^{2}$ & $\mathrm{R}^{2}$ & $\mathrm{~F}$ & Sig. \\
\hline (Constant) & 1.688 & .825 & & 2.044 & .080 & .686 & .470 & .394 & 6.20 & .041 \\
Mission & .445 & .179 & .686 & 2.492 & .041 & & & & & \\
Definition & .45 & & & & & & & & & \\
\hline
\end{tabular}

The statistics in Table 3 show that at the .05 level of significance, mission definition predicted the lecturers' job performance by a significant $39.4 \%$ (Adjusted $\mathrm{R}^{2}=.394, \mathrm{~F}=6.209$, Sig. $=.041<.05$ ). The corresponding Beta, $\mathrm{R}$ and $\mathrm{t}$-values were all positive and significant $(\mathrm{Beta}=\mathrm{R}=.686, \mathrm{t}=2.492$, Sig. $=$ .041). This implies that the heads of departments' definition of their universities' missions and lecturers' job performance varied in the same direction. Therefore, a positive change in the way the heads of department define their universities' mission results into a significant improvement in lecturers' job performance.

The third objective of the paper was to analyse how the way their heads of departments managed instructional programmes influenced lecturers' job performance. This objective was met using the same approach applied to achieve the previous objective. The descriptive findings obtained from respondents' assessment of how the heads of departments managed instructional programmes are shown in Table 4. 
Table 4: Assessment of instructional management by heads of departments

Min Max Lecturers $(\mathrm{N}=341) \quad \operatorname{HODs}(\mathrm{N}=35) \quad$ Total

The department head plays a leading role in deciding which academic programmes should be offered in the department.

The department head encourages only any academic programmes that facilitate realisation of the university's curriculum goals.

Min Max Lecturers $(\mathrm{N}=341)$

HODs $(\mathrm{N}=35)$ Total

All lecturers in the department are supervised by inspiring them through checking and improving the content of lectures they teach.

Department head monitors lecturers by checking on how they lecture so he/she can pedagogically guide them to improve where necessary.

\begin{tabular}{lllll}
1 & 5 & 3.58 & 4.18 & 3.88 \\
1 & 5 & 4.19 & 4.11 & 4.15 \\
1 & 5 & 4.01 & 4.44 & 4.23 \\
1 & 5 & 3.69 & 4.14 & 3.92 \\
1 & 5 & 2.22 & 3.55 & 2.89 \\
1 & 5 & 3.87 & 3.88 & 3.87 \\
& & & & \\
1 & 5 & 3.65 & 3.87 & 3.76 \\
& & 3.60 & 4.02 & 3.81 \\
\hline
\end{tabular}


Results in Table 4 show that there were respondents who showed that their heads of departments did not manage instructional programmes $(\min =1)$ and those who indicated that the heads managed the programmes to their expectation (max $=5$ ). Most of the mean values were close to ' 4 ', suggesting that on average, respondents agreed and therefore showed that the heads of departments managed instructional programmes below lecturers' expectation. The findings obtained from linear regression conducted to establish how managing instructional programme predicted (influenced) lecturers' job performance are summarized in Table 5.

Table 5: Instructional Programme Management and Lecturers' Job Performance

\begin{tabular}{|c|c|c|c|c|c|c|c|c|c|c|}
\hline Predictors & B & $\begin{array}{l}\text { Std. } \\
\text { Error }\end{array}$ & Beta & $\mathrm{t}$ & Sig. & $\mathrm{R}$ & $\mathrm{R}^{2}$ & $\begin{array}{l}\text { Adjusted } \\
\mathrm{R}^{2}\end{array}$ & $F$ & Sig. \\
\hline $\begin{array}{l}\text { (Constant) } \\
\text { Instructional }\end{array}$ & 1.436 & .441 & & 3.254 & .041 & .895 & .802 & .773 & 28.267 & .001 \\
\hline $\begin{array}{l}\text { programme } \\
\text { management }\end{array}$ & .627 & .118 & .895 & 5.317 & .001 & & & & & \\
\hline
\end{tabular}

The statistics in Table 5 indicate that at the .05 level of significance, instructional programme management by heads of department predicted the lecturers' job performance by a significant $77.3 \%$ (Adjusted $\mathrm{R}^{2}=.773, \mathrm{~F}=28.267$, Sig. $=.001$ $<.05)$. The corresponding Beta, $\mathrm{R}$ and $\mathrm{t}$-values were all positive and significant $($ Beta $=\mathrm{R}=.895, \mathrm{t}=5.317$, Sig. $=.001)$. This reveals that the management of instructional programmes by the heads of departments and lecturers' job performance varied in the same direction. Therefore, a positive change in the way the heads of department manage instructional programmes translates into a significant improvement in lecturers' job performance.

The fourth and last objective of the paper was to analyse how the way their heads of departments promoted a supportive teaching-climate influences this job performance. Similar methods were used to realise this objective. Descriptive findings obtained from respondents' assessment of how a supportive teachinglearning climate was promoted are depicted in Table 6. 
Table 6: Assessment of promoting a supportive teaching-climate

\begin{tabular}{|c|c|c|c|c|c|}
\hline & Min & Max & $\begin{array}{l}\text { Lecturers }(N= \\
341)\end{array}$ & $\begin{array}{l}\text { HODs }(\mathrm{N}= \\
35)\end{array}$ & Total \\
\hline The university has all the materials I need to lecture to my best. & 1 & 5 & 1.58 & 1.18 & 1.38 \\
\hline The university has all the equipment I need to lecture to my best. & 1 & 5 & 2.19 & 2.11 & 2.15 \\
\hline The lecture rooms are spacious and ventilated enough to support effective teaching. & 1 & 5 & 2.19 & 1.13 & 1.66 \\
\hline My immediate supervisor ensures that no working time is wasted. & 1 & 5 & 1.22 & 1.52 & 1.37 \\
\hline $\begin{array}{l}\text { The university provides opportunities lecturers need to pursue desired professional } \\
\text { development }\end{array}$ & 1 & 5 & 1.87 & 1.81 & 1.84 \\
\hline Lecturers who teach as expected are rewarded & 1 & 5 & 1.44 & 1.15 & 1.30 \\
\hline $\begin{array}{l}\text { I always available at the appointed time to supervise research students allocated to } \\
\text { me. }\end{array}$ & 1 & 5 & 1.43 & 2.25 & 1.84 \\
\hline I am always available to attend to students' non-research learning needs. & 1 & 5 & 1.22 & 2.15 & 1.67 \\
\hline students are given chance to freely express their learning concerns & 1 & 5 & 1.33 & 1.45 & 1.39 \\
\hline
\end{tabular}


From Table 6, there were respondents who strongly disagreed that a supportive teaching-climate was promoted in their universities $(\min =1)$ and those who strongly agreed to the contrary $(\max =5)$. Most of the mean values were however close to ' 2 ', suggesting that on average, respondents disagreed, thereby showing that a supportive teaching-climate was not promoted. Results obtained from linear regression conducted to establish how promoting a supportive teachingclimate predicted lecturers' job performance are shown in Table 7.

Table 7: Supportive Teaching-Climate and Lecturers' Job Performance

\begin{tabular}{lllllllllll}
\hline Predictors & $\mathrm{B}$ & $\begin{array}{l}\text { Std. } \\
\text { Error }\end{array}$ & Beta & $\mathrm{t}$ & Sig. & $\mathrm{R}$ & $\mathrm{R}^{2}$ & $\begin{array}{l}\text { Adjusted } \\
\mathrm{R}^{2}\end{array}$ & $\mathrm{~F}$ & Sig. \\
\hline $\begin{array}{l}\text { (Constant) } \\
\text { Promotion } \\
\text { of }\end{array}$ & 1.600 & .497 & & 3.218 & .015 & .856 & .733 & .695 & 19.250 & .00 \\
$\begin{array}{l}\text { supportive } \\
\text { teaching } \\
\text { climate }\end{array}$ & .600 & .137 & .856 & 4.387 & .003 & & & & & \\
\hline
\end{tabular}

Results in Table 7 show that at the .05 level of significance, promotion of supportive teaching-climate predicted the lecturers' job performance by a significant $69.5 \%$ (Adjusted $\mathrm{R}^{2}=.695, \mathrm{~F}=19.250$, Sig. $=.003<.05$ ). The corresponding Beta, $\mathrm{R}$ and $\mathrm{t}$-values were all positive but significant $(\mathrm{Beta}=\mathrm{R}=$ $.856, \mathrm{t}=4.387, \mathrm{Sig} .=.003)$. These statistics reveal that promoting a supportive teaching-climate and lecturers' job performance varied in the same direction. Therefore, a positive change in promoting a supportive teaching-climate translates into a significant improvement in lecturers' job performance.

\section{Discussion, Conclusion and Recommendations}

Findings suggest that on average, Uganda's public universities are still grappling with lecturers' job underperformance (Table 1). This underperformance was reported in all the dimensions of the lecturers' job, but it was more critical in the conducting of research and participation in community service than in the teaching dimension (Table 1). The findings therefore, support the observations made in the studies of Nassuna (2013), Kakulu (2016), Ddungu (2017, 2018a, 2018b) and Wakida et al. (2018). Each of these studies revealed that while the job performance of lecturers was below expectation in the teaching dimension, underperformance was worse in research and community service. The findings suggest that the lecturers are not effectively contributing to the university's realisation of the purpose of preparing the highest level of human capital Uganda needs to foster her innovative and sustainable national development as desired. 
Therefore, solutions by which lecturers' job underperformance can be dealt with are urgently needed.

Fortunately, the findings in Tables 3, 5 and 7 indicate that how the three dimensions of instructional leadership were conducted in the selected universities predicted the lecturers' job performance in a significantly positive manner. Not only do these findings concur with the model proposed by Hallinger and Murphy (1985) as well as the studies of Hallinger (2003), Ndungu (2015), Adams (2016), Lyonga (2018), and Yousaf et al. (2018) each of which showed that at least one of the three dimensions of instructional leadership relates positively with teachers' job performance. More importantly, the findings also suggest that any positive change in each of these dimensions leads to a significant improvement in the lecturers' job performance. In other words, public universities in Uganda can significantly solve the lecturers' job underperformance facing them by focusing on ameliorating their instructional leadership.

Such focus is particularly needed in the light of the findings in Tables 2, 4 and 6. Each of these tables indicates that the manner in which each dimension of instructional leadership was carried out at the selected universities did not match respondents' expectations. The heads of departments did not articulate the universities' missions to the lecturers neither did they manage academic programmes as lecturers expected. In addition, the teaching-climate was not promoted to the lecturers' expectations. Accordingly, this paper recommends the heads of departments of the Uganda's public universities to improve the manner in which they communication their universities' mission to the lecturers. This will enable the lecturers to comprehend the mission well and work towards achieving it. The department heads should also improve the degree to which they manage the academic programmes offered in their respective departments. They should particularly pay attention to improving how they supervise, monitor, appraise and provide feedback about the job performance of the lecturers whom they supervise. Furthermore, the public universities in Uganda should improve their teaching-climate by ensuring that all the teaching and learning facilities lecturers and students need to teach and learn are made available. Being public universities implies that these institutions' top management should lobby government to increase the funding of their instructional budget.

\section{References}

Adams, E. J. (2016). The effects of reviewing a school's mission and vision on teacher stress. Unpublished Masters Dissertation: St. Catherine University. Alfagira, S.A., bin Zumrah, R., bin Mond Noor, K., \& bin Ab, O. (2017). Investigating the factors influencing academic staff performance: A 
conceptual approach. Rahman Scholars Journal of Economics, Business and Management, 4(11), 842-848.

Amin, M., Shah, R.U., Ayaz, M., \& Atta, M.A. (2013). Teachers' job performance at secondary level in Khyber Pakhyunkhwa, Pakistan. Gomal University Journal of Research, 29(2), 100-104.

Barth-Farkas, F., \& Vera, A. (2014). Power and transformational leadership in public organizations. International Journal of Leadership in Public Services, 10(4), 217-232.

Burkus, D. (2010). Transformational leadership theory. Retrieved from https://davidburkus.com/2010/03/transformational-leadership-theory/

Burns, J.M. (1978). Leadership. New York: HarperCollins.

Chen, S.S. (2014). The effects of transformational leadership of principals on student academic achievement (Doctoral Thesis, California State University)

Chen, Y.G. (2017). Exploring differences from principals' leaderships and teachers' teaching performances in public and private schools. The Journal of International Management Studies, 12(2), 65-85.

Creswell, J.W., and Creswell, J.D. (2018). Research design: Qualitative, quantitative, and mixed methods approaches (5th Ed.). Thousand Oaks, CA: Sage

Day, D.V., \& Harrison, M.M. (2007). A multilevel, identity-based approach to leadership development. Human Resource Management Review, 17(4), 360373.

Ddungu, L. (2017). Challenges of supervising postgraduate educational research and their effects on its quality in universities in Uganda. Makerere Journal of Higher Education, 7(1), 13-29.

Ddungu, L. (2018a). Evaluation as a predictor of academic staff participation in community service in universities in Uganda. Makerere Journal of Higher Education, 8(2), 3-19.

Ddungu, L. (2018b). Herzberg's and Maslow's motivation theories as comparable predictors of academic staff motivation in public universities in Uganda. Upcoming Journal Article. Makerere Journal of Higher Education, 10(2), 33-48.

Dhuey, E., \& Smith, J. (2014). How school principals influence student learning. Discussion Paper No. 7949. Bonn: The Institute for the Study of Labour (IZA).

Ersozlu, A., \& Saklan, E. (2016). Instructional leadership in higher education: how does it work? British Journal of Education, 4(5), 1-15.

Hallinger, P. (2003). Leading educational change: Reflections on the practice of instructional and transformational leadership. Cambridge Journal of Education, 33(3), 329-352.

Hallinger, P. (2007). Research on the practice of instructional and transformational leadership: Retrospect and prospect. Australian Council for Educational Research, ACE Research 
Hallinger, P., \& Murphy, J. (1985). Assessing the instructional leadership behaviour of principals. Elementary School Journal, 86(2), 217-248.

Hassel, S., \& Ridout, N. (2018). An investigation of first-year students' and lecturers' expectations of university education. Frontiers in Psychology, 8, 2218-2233.

Hirshleifer, S.R. (2016). Incentives for effort or outputs? A field experiment to improve student performance. Retrieved from https://www.povertyactionlab.org/sites/default/files/publications

Hompashe, D. (2018). Instructional leadership and academic performance: Eastern Cape educators' perceptions and quantitative evidence. Stellenbosch Economic Working Papers: WP13/2018. Department of Economics and the Bureau for Economic Research, University of Stellenbosch

Hughes, T.A. (2014). Idealised, inspirational and intellectual leaders in the social sector: transformational leadership and the Kravis Prize. CMC Senior Theses. Paper $906 . \quad$ Retrieved from http://scholarship.claremont.edu/cmc theses/906

Igbojekwe, P.A., Ugo-Okoro, C.P., \& Agbonye, C.O. (2015). Performance evaluation of academic staff in universities and colleges in Nigeria: The missing criteria. International Journal of Education and Research, 3(3), 627640.

Kakulu, P. (2016). Staff development programmes and academic staff performance of universities in Uganda: A case of Kyambogo University, Uganda (Masters Dissertation, Kyambogo University).

Kezar, A.J., \& Holcombe, E.M. (2017). Shared leadership in higher education: Important lessons from research and practice. Washington, DC: American Council on Education.

Kipsangut, D.B. (2012). Effect of incentives on teachers' performance as perceived by primary school teachers in Eldoret Municipality, Uasin-Gishu County, Kenya (Masters Dissertation, Mount Kenya University).

Laska, L. (2016). Monitoring and Evaluating the Performance of Teachers through the Process of Observation in the Classroom. European Journal of Multidisciplinary Studies, 1(2), 370-378.

Liang, X., Kidwai, H., \& Zhang, M. (2016). Financing education for quality and equity: How Shanghai does it, In World Bank (Ed), Insights and lessons from the highest-ranking education system in the world (pp.47-68). Washington DC: World Bank and IBRD.

Lineburg, P.N. (2010). The influence of the instructional leadership of principals on change in teachers' instructional practices (Doctoral Dissertation, Virginia State University).

Lyonga, N.A.N. (2018). Supervision and teachers' work performances in primary schools in Konye Sub-Division in Cameroon. Journal of Educational and Social Research, 8(2), 115-124 
Mbithi, A.M., K'Obonyo, P.O., \& Awino, Z.B. (2016). Transformational leadership, employee outcomes, and performance of universities in Kenya. DBA Africa Management Review, 6(2), 1-20.

McCarthy, J. (2015). 3 ways to plan for diverse learners: What teachers do? Retrieved from http://www.edutopia.org/blog/differentiated-instructionways-to-plan-john-mccarthy

McCleskey, J.A. (2014). Situational, transformational, and transactional leadership and leadership development. Journal of Business Studies Quarterly, 5(4), 117-130.

McCrimmon, M. (2008). Transformational leadership: Benefits and limitations of transformational leadership. Retrieved from http://www.suite.com

Money, V.O. (2017). Effectiveness of transformational leadership style in secondary schools in Nigeria. Journal of Education and Practice, 8(9), 135140.

Naseer, M. S. (2010, April). Factors affecting the role performance of academic staff in the Maldives College of Higher Education. Paper presented at the Second Annual International Research Conference on Social Sciences and Humanities, Bangkok, Thailand.

Nassuna, A. (2013). Team building as a challenge of student completion and measure of lecturers' effectiveness at the College of Education and External Studies, Makerere University. Unpublished Masters Dissertation. Kampala: Makerere University.

National Council for Higher Education. (2018). Higher education standards investigation report. Kampala: National Council for Higher Education.

Ndiritu, A.W. (2012). Effects of principals' transformational leadership characteristics on students' academic performance in secondary schools in Nairobi County, Kenya (Masters Dissertation, Nairobi University).

Ndungu, B.W., Gathu, A., \&. Bomett, E.J. (2015). Influence of monitoring and evaluation by principals on effective teaching and learning in public secondary schools in Githunguri District. Journal of Education and Practice, 6(9), 1018.

Nusair, N., Abaaneh, R., \& Bae, Y. K. (2012). The impact of transformational leadership style on innovation as perceived by public employees in Jordan. International Journal of Communication and Management, 22(3), 182-201.

Onoyase, A. (2017). Motivation and job performance of lecturers of tertiary institutions in Nigeria: Implication for counselling. Retrieved from https://www.researchgate.net/publication/316330595_Motivation_and_Job_ Performance_of_Lecturers_of_Tertiary_Institutions_in_Nigeria_Implication for_Counseling

Pearce, M.L. (2017). The effects of instructional leadership on teacher efficacy (Doctoral Dissertation, Kennesaw State University). 
Pink, D.H. (2009). Drive: The surprising truth about what motivates us. New York: Riverhead Books.

Sadeghi, A. \& Pihie, Z.A.L. (2013). The role of transformational leadership style in enhancing lecturers' job satisfaction. International Journal of Business and Social Science, 4(8), 8-24.

Sanga, P. L. (2017). Challenges and opportunities for quality assurance of crossborder higher education in East Africa, In Ssempebwa, J., \& Neema-Abooki, P. (Eds), Innovating university education: Issues in contemporary African higher education. Kampala: Fountain Publishers.

Ssesanga, K., \& Garrett, R. M. (2005). Job satisfaction of university academics: Perspectives from Uganda. Higher Education, 50(1), 33-56.

Victor, A.A., \& Babatunde, E.G. (2014). Motivation and effective performance of academic staff in higher education: Case study of Adekunle Ajasin University, Ondo State, Nigeria). International Journal of Innovation and Research in Educational Sciences, 1(2), 157-163.

Wakida, E., Maling, S., \& Obua, C. (2018). Mbarara University research training initiative: a spin-off of the medical education partnership initiative in Uganda. Advances in Medical Education and Practice, 8, 527-533.

Wong, B., \& Yuan-Li, T.C. (2019). Let me entertain you: the ambivalent role of university lecturers as educators and performers, Educational Review, 71(2), 218-233.

Yin, Robert K. (2014). Case study research: Design and methods (5th Ed.). Thousand Oaks, CA: Sage.

Yousaf, Usman S., Usman, Bushra, \& Islam, Talat. (2018). Effects of Supervision Practices of Principals on Work Performance and Growth of Primary School Teachers. Bulletin of Education and Research, 40(1), 285298.

Yu, B. (2013). The influence study of transformational leadership in university on teachers' organizational commitment: the construction and verification of a theoretical model. Canadian Social Science, 9(4), 126-137. 